\title{
Comprehensive Dental Management of Children with Henoch-Schonlein Purpura: A Literature Review
}

\author{
Vera Yulina $^{1 *}$, Willyanti Suwondo ${ }^{2}$ \\ ${ }^{1}$ Departement of Paediatric Dentistry, Faculty of Dentistry University of Syiah Kuala, Indonesia \\ ${ }^{2}$ Departement of Paediatric Dentistry, Faculty of Dentistry University of Padjajaran, Indonesia \\ *correspondence: ${ }^{1}$ vera.yulina@unsyiah.ac.id ; ${ }^{2}$ willyanti.soewondo@fkg.unpad.ac.id
}

\begin{abstract}
Introduction: Henoch-Schonlein purpura is the most common childhood vaskulitis, affecting 10-20 children per 100.000 per year. More than $90 \%$ of patients are under 10 years old with a mean age of 6 years. It is characterized by non-thrombocytopenic purpura, arthritis, abdominal pain and gastrointestinal bleeding, and nephritis leading to renal failure in children. The most common factor that triggers this disease is bacterial invasion, especially the infection foci that is often found in the children oral cavity. Therefore, a comprehensive oral and dental management have to carried out. Purpose: The purpose of this article is to make a review of dental and oral care in children with HSP. Reviews: focal infection in the child's oral cavity can be a trigger of HSP. Pathogenesis of HSP is associated with complex diseases that are contributed by genetic factors and environmental triggers, one of which is odontogenic infection. A lesion could contain a thousand billion colonies of both aerobic and anaerobic bacteria. Various inflammatory cells in the form of cytokines are produced by cellular components of periapical lesions that activate immune reactions, therefore odontogenic infections, especially chronic apical periodontitis, have the potential to trigger HSP. Management of focal odontogenic infections could reduce the incidence of HSP especially HSP with kidney involvement. Conclusion: Comprehensive care needs to be taken to prevent recurrence of the disease and to limit the complications.
\end{abstract}

Keywords: Henöch-Schonlein Purpura, focal infection

\section{INTRODUCTION}

Henöch-Schonlein Purpura (HSP) is a systemic vasculitis mediated by an immune complex that attacks small blood vessels with clinical manifestations of palpable cutaneous purpura, joint pain, renal involvement, abdominal colic pain and gastrointestinal bleeding. ${ }^{1-3}$ The HSP syndrome is characterized by purpura. palpable without thrombocytopenia which is usually spread to dependent sites such as the lower extremities, arms, buttocks, arthritis or arthralgia, abdominal pain or gastrointestinal bleeding and renal involvement. ${ }^{4,5}$ In HSP patients, immune complex immunoglobulin A (IgA) have deposits in small blood vessels due to exposure to antigens of upper respiratory tract infections, medications, vaccinations, malignancies and odontogenic infections. ${ }^{6,7}$

The epidemiology of HSP averages around 14 cases per 10,000 school-age children with a high prevalence occurring at ages $2-11$ years $(75 \%)$ with a peak incidence at 6 years of age and more common in boys than girls with ratio $2: 1,0^{3,8-10}$ The annual incidence of HSP in the United Kingdom is estimated at 20.4 cases per 100,000 children under 17 years of age, while in Asia it has a higher rate of 24.0 cases per
100,000 children. ${ }^{2}$ The prevalence of HSP in Indonesia, to be exact at Hasan Sadikin Hospital Bandung tends to increase from 2.7/100,000 in 2008 to $5.2 / 100,000$ in 2010 with a male to female ratio of 1.8:1. The mean age of occurrence of HSP was $7.9 \pm$ 2.9 years with an age range of 6 months to 15 years. Peak morbidity between 5 to 10 years. ${ }^{11}$

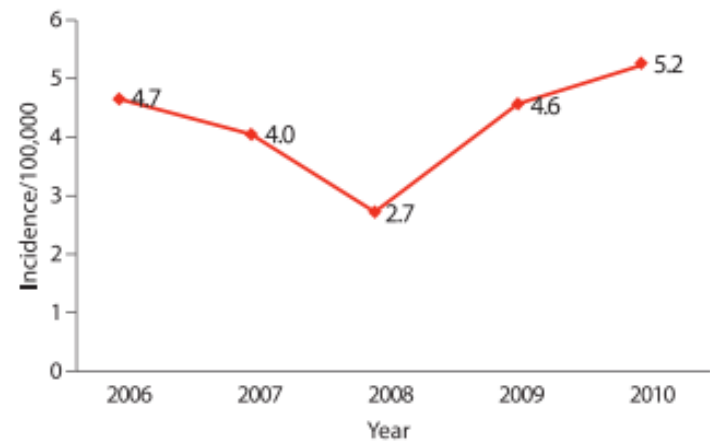

Figure 1. Incidence of Henoch-Schonlein purpura in Indonesia (Hasan Sadikin Hospital, Bandung). ${ }^{11}$

Children and adolescents with special needs have a high risk of disease in the oral cavity related to their limitations in maintaining oral health. There is a 
correlation that poor oral health can trigger the occurrence of certain systemic diseases, one of which is Henöch-Schonlein Purpura (HSP). ${ }^{8,12}$ Therefore, in such individuals, excellent knowledge is needed in maintaining oral health carefully.

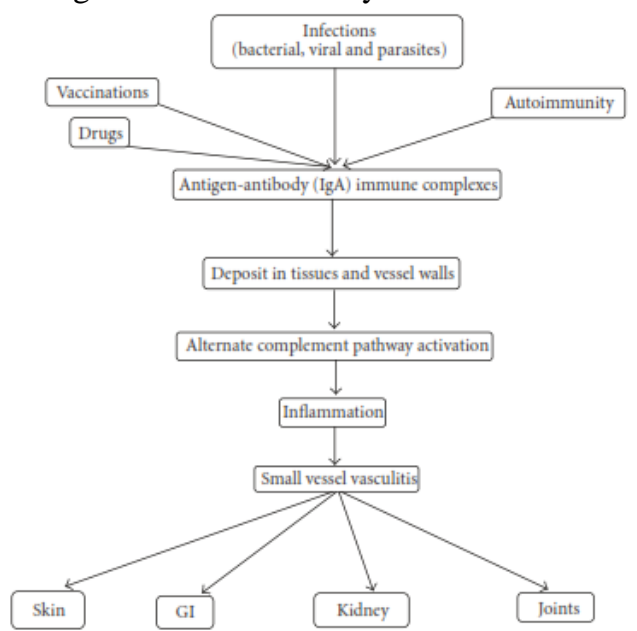

Figure 2. Schematic Diagram of the Pathophysiology of $\mathrm{HSP}^{16}$

The pathogenesis of HSP is not clearly known, but this syndrome is associated with a complex disease that is contributed by genetic factors and environmental triggers. Clinical evidence supports the hypothesis that infectious agents such as parvovirus B19, HBV and HCV, Adenovirus, -hemolytic Streptococcus Group A, Staphylococcus aureus and Mycoplasma may be predisposing factors to the occurrence of HSP in children.,3,13 Group A streptococci are agents The main cause of upper respiratory tract infection is the main pathogenic microorganism that most often causes HSP, besides that odontogenic infections are also suspected of being the causative agent of HSP.?

HSP disease histologically demonstrates an immune-mediated leukocytoclastic vasculitis with deposition of $\operatorname{IgA}$ and immune complexes in the vessel wall and involved organs. There was an increase in serum IgA levels, IgA immune complexes, anticardiolipin $\operatorname{IgA}$ antibodies, and transforming growth factor- $\beta$ as well as changes in $\operatorname{IgA}$ glycosylation. Antigen and antibody complexes, the majority of which $\operatorname{IgA}$ are formed as a result of bacterial and viral infections, vaccinations, drugs, and autoimmune mechanisms. These antigen-antibody complexes deposit in the walls of small blood vessels and activate the alternative complement pathway, resulting in the accumulation of neutrophils, leading to inflammation and vasculitis without a granulomatous reaction. Vasculitis results in extravasation of blood vessels and their components into the interstitial spaces, causing edema and bleeding. ${ }^{14,15}$

Peripheral blood examination of HSP patients can show leukocytosis with eosinophilia and a shift in the differential count to the left, normal or increased platelet counts, this is what distinguishes HSP from ITP (Idiopathic Thrombocytopenic Purpura), besides that the erythrocyte sedimentation rate can increase. Elevated levels of urea and creatinine indicate involvement of renal function or dehydration. Biopsy of skin lesions in HSP patients revealed leukocytoclastic vasculitis. Immunofluorescence indicates the presence of $\operatorname{IgA}$ and complement deposits in the vessel wall. ${ }^{3}$

Clinical symptoms of HSP patients $1 / 2$ to $2 / 3$ cases in children are characterized by upper respiratory tract infections that appeared 1-3 weeks earlier in the form of low-grade fever and headache. Arthralgia and arthritis are found to occur before skin disorders (1-2 days), especially affecting the knees and ankles, can also affect the wrists, elbows and joints of the fingers. The joints experience temporary swelling and pain and do not cause permanent deformity. Skin disorders are found in $95-100 \%$ of cases, $50 \%$ of which are complaints from patients when they come for treatment; in the form of a symmetrical macular rash, especially on the skin that is often exposed to pressure, namely the back of the leg, buttocks, and arm on the side of the ulna. The macula turns into a purpuric lesion within 24 hours, first red, then turns purple to yellowish brown then disappears and new skin disorders may reappear. ${ }^{3}$

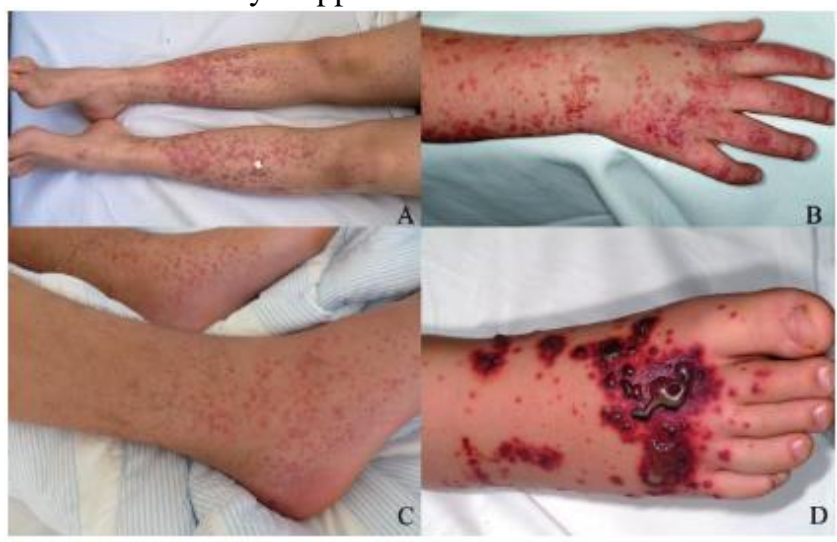

Figure 3. (A and B) Classical skin lesions occurring in Henoch-Schönlein purpura, with palpable purpura on the extremities. (C) arthritis and purpura of the lower extremities. (D) Bullous and necrotic lesions present on the lower extremities of a patient with complicated Henoch-Schönlein purpura. ${ }^{9}$

The clinical manifestations of HSP systemic vasculitis basically involve multiple organs, but the classic characteristics appear on the skin, joints, gastrointestinal and kidney. ${ }^{16,17,18}$ Henöch-Schonlein Purpura (HSP) partially resolves spontaneously with early intervention with supportive therapy, but can also develop to be more severe with a high recurrence 
rate. A serious long-term complication of HSP is Nephritis. ${ }^{6,11}$

HSP diseases such as dermatological and autoimmune diseases, some of which are correlated with odontogenic infectious diseases, ${ }^{19}$ such as Burger's disease associated with periodontitis, palmoplantar pustulosis and pigmentation purpura have also been reported to be associated with focal oral infections. . $^{7,20,21}$

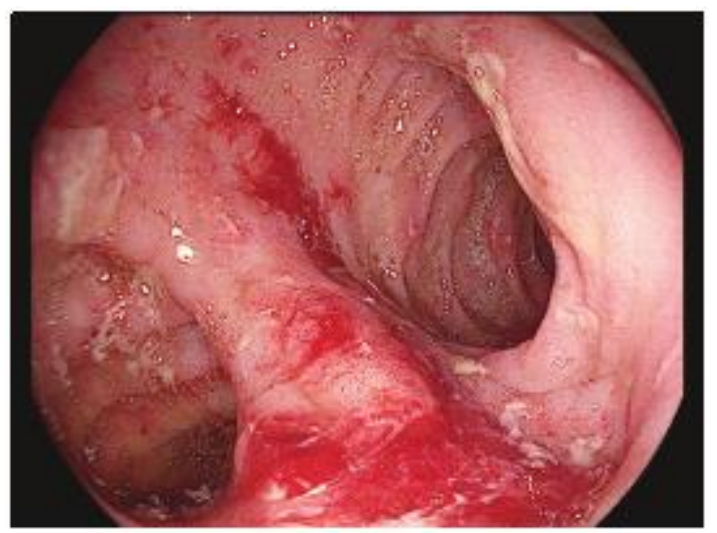

Figure 4. Endoscopic view of the esophagus showing inflammation, submucosal bleeding and small ulcerations. ${ }^{15}$

According to the criteria of the American College of Rheumatology in 1990, it was stated that if it meets at least 2 of the 4 following symptoms, the diagnosis of HSP can be made. First, nonthrombocytopenia palpable purpura. Second, the onset of the first symptoms is less than 20 years. All three had bowel angina and fourth on a biopsy revealed granulocytes in the walls of the arterioles or venules. ${ }^{3}$ The literature states that HSP has a high probability of spontaneously recovering if supportive care is the main intervention that has been carried out, but sometimes it can progress to a more severe condition with a high recurrence rate. ${ }^{7,22}$

The European League Against Rheumatism (EULAR) and the Pediatric Rheumatology European Society (PRES) in 2008 made the diagnostic criteria, namely the presence of purpura or nonthrombocytopenia petechiae with a predominant location in the lower extremities accompanied by at least one or more of the following symptoms:

1. Diffuse abdominal pain in the form of colic and diffuse pain with acute onset.

2. Histopathological appearance shows leukocytoclastic vasculitis with predominant IgA deposits in the skin or glomerular proliferative nephritis with dominant $\operatorname{IgA}$ deposits.

3. Acute arthritis in the form of joint swelling or joint pain with limited motion, or the presence of arthralgia, namely joint pain without swelling or limitation of motion.
4. Renal involvement (hematuria or proteinuria). Urinalysis shows proteinuria $>0.3 \mathrm{~g} / 24 \mathrm{~h}$ or albumin/keratin ratio $>30$ $\mathrm{mmol} / \mathrm{mg}$ in morning urine. Hematuria or red blood cells $>5 /$ LPT or dipstick greater than +2 on dipstick. ${ }^{2,16}$

Laboratory tests include routine blood and urine tests, bleeding time, blood clotting time, platelet count, LE cells, blood sugar, ASO titre, serum electrolysis, cryoglobulin, ANA, RA factor, kidney function test, liver function test, peripheral smear, culture throat swab and sensitivity, chest X-ray examination and skin biopsy. ${ }^{10}$

Table 1. Diagnosis using ACR (1990) or EULAR/PRINTO/PRES $(2008)^{11}$

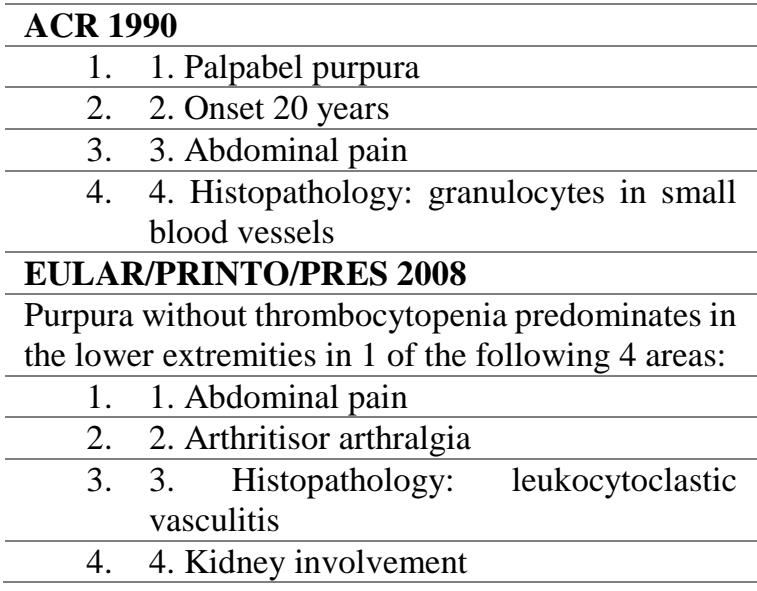

Tahmassebi et $\mathrm{al}^{23}$ have reported a case of HSP that occurred after endodontic treatment. Root canal treatment is thought to be a precipitating factor for HSP due to trepanation procedures at the apex which may result in streptococcal bacteremia due to changes in the environment and microbial flora of the root canal. Case reports showed that the presence of mandibular pain, gingivitis and petechiae indicated a recurrence of $\mathrm{HSP} .{ }^{24}$ Inoue et $\mathrm{al}^{25}$ reported the success of dental treatment in preventing nephropathy in pediatric patients with HSP. Igawa et $\mathrm{al}^{26}$ reported that focal oral infection could be a precipitating factor for HSP in adult patients. A study conducted by Abe et al in their case report concluded that periodontal infection and apical periodontitis were the main candidate factors for the development of HSP in these patients. ${ }^{7}$

Ghrahani et $\mathrm{al}^{11}$ in their research conducted at the Department of Pediatrics at Hasan Sadikin Hospital (RSHS) Bandung from 2006 to 2011 found that $13.3 \%$ of HSP cases were probably caused by odontogenic infections. Another study also conducted at RSHS Bandung in 2013 found that in 41 patients with HSP with kidney involvement, odontogenic infection was the most precipitating factor compared 
to other precipitating factors, as many as 25 patients, ${ }^{27}$ this requires special attention because it can become a focus of infection. ${ }^{11}$

All these data indicate that chronic infection that occurs in the oral cavity plays a role in the occurrence of the pathogenic process in HSP. The high caries rate in children with HSP supports this theory. ${ }^{6}$ Caries in primary teeth can easily invade through infected root canals into the surrounding bone tissue and form apical periodontitis ${ }^{28}$

A thousand billion colonies of both aerobic and anaerobic bacteria can be contained in a single lesion. Inflammatory cells in the form of cytokines produced by cellular components of the periapical lesion activate an immune response. ${ }^{6,28}$ Bacterial degradation products and decomposition products of pulp tissue remain in the lesion so that bacteria, their toxic and destroyed peripheral tissue can exit through the apical foramen and continue into the tonsils. through the epithelial surface. ${ }^{6}$ The oral mucosal innate $\operatorname{sg} \mathrm{A}$ immune system in this condition fails to eliminate bacterial antigens because there are too many bacteria. Bacterial pathogens on the other hand can enter the blood vessels during transient bacteremia and damage the inner lining of the blood vessel walls, therefore odontogenic infections, especially chronic apical periodontitis, are potential triggers for HSP. ${ }^{27,28}$

The results of a study conducted by Abe et al7 showed that proper treatment of focal odontogenic infections can help heal HSP. Nakaseko et $\mathrm{al}^{29}$ also stated that comprehensive management of dental infections would reduce the incidence of HSP with renal involvement. Patients with HSP need to be consulted to the Dental and Oral Department to find a focus of infection and comprehensive management to prevent the occurrence of HSP with renal involvement. ${ }^{27}$

Children with HSP, as well as patients with certain medical conditions (such as cardiovascular disease) also need to be carefully considered as candidates for patients requiring prophylactic antibiotic therapy prior to dental procedures. This condition is due to various studies showing that odontogenic infections and dental procedures have the potential to trigger HSP with renal involvement in pediatric patients. ${ }^{6,12,23}$ Foci of active infection present in the oral cavity of children who have had HSP especially those with severe renal involvement should be completely removed to prevent the spread of infection to other internal organs such as the kidneys or skin which can lead to serious systemic disturbances and worsen the prognosis of the disease. ${ }^{12}$

Research reports report that one active infectious lesion in the oral cavity can contain 300 species of aerobic and anaerobic bacteria. These pathogens produce various inflammatory cytokines and cell degradation derivatives that can enter the bloodstream during the transient phase of bacteremia which ultimately results in damage to the inner lining of the blood vessel wall and persistence of active immune reactions. The decision to use prophylactic antibiotics should be made with the patient's pediatrician or nephrologist after a comprehensive evaluation of the patient's health status. ${ }^{12}$

\section{DISCUSSION}

Henöch-Schonlein Purpura (HSP) is an inflammatory disease that rarely occurs in children, but it is one of the main causes of systemic vasculitis in children, especially those aged 3-10 years. ${ }^{12,2}$ HSP syndrome is characterized by palpable purpura without thrombocytopenia. which are usually scattered in dependent parts such as the lower extremities, arms, buttocks, arthritis or arthralgia, abdominal pain or gastrointestinal bleeding and renal involvement. ${ }^{4,5}$ HSP has clinically relevant correlations with the field of pediatric dentistry. ${ }^{12}$

A lot of research to study HSP has been done. The results showed that there was a correlation between this disease and odontogenic infection which acts as a focal infection that triggers the emergence of the disease, but only a few studies have studied the management of oral care in these patients. Research conducted at Hasan Sadikin Hospital (RSHS) Bandung stated that there was an increase in the incidence of HSP from 2008 to 2010, and most patients had odontogenic infections. ${ }^{11,27}$ In line with research conducted by Igawa et al 26 who reported that focal oral infections may be a precipitating factor for HSP. Research conducted by Abe et $\mathrm{al}^{7}$ in their case report concluded that periodontal infection and apical periodontitis are the main candidate factors causing HSP in these patients, ${ }^{7}$ therefore, it is very important to maintain comprehensive oral health in HSP patients.

Dental treatment has the potential to trigger this disease, this is in line with a study conducted by Tahmassebi et $\mathrm{al}^{23}$ who reported a case of HSP that occurred after endodontic treatment. Three important points should be carefully considered by pediatric dentists when treating HSP patients. First, HSP disease can occur as a consequence of dental treatment, such as tooth extraction, root canal treatment or periodontal therapy. Second, children with HSP are more susceptible to the occurrence of diseases in the oral cavity, especially dental caries $(70 \%)$ and apical periodontitis $(5 \%)$. Third, in children who have developed HSP especially with severe renal involvement, the foci of active infection present in the oral cavity should be completely removed to prevent the spread of infection to other internal organs such as the kidneys or skin which can lead to serious systemic disorders and worsen the prognosis of the disease. ${ }^{12}$

It is important to maintain oral health in children with HSP, because the oral cavity is the main 
entry point for bacteria that can increase the risk of other systemic disorders during the development of the disease itself. Comprehensive preventive care should be given to these patients, particularly focusing on maintaining good oral health, application of fluoride varnish, dietary counseling, and closure of pits and fissures. ${ }^{12,7}$

\section{CONCLUSION}

A pediatric dentist must be knowledgeable and aware of HSP disease and the importance of maintaining the overall health status of the patient's oral cavity to prevent additional systemic complications. This responsibility is shared with other healthcare practitioners, such as pediatricians and nephrologists. The main goal is to always improve the quality of life of oral health in HSP patients.

\section{REFERENCES}

1. Park SJ, Suh JS, Lee JH, Lee JW, Kim SH, Han $\mathrm{KH}$, et al. Advances in our understanding of the pathogenesis of Henoch-Schönlein purpura and the implications for improving its diagnosis. Expert Rev Clin Immunol. 2013;9(12):1223-38.

2. Rachmadi D, Sekarwana N, Hilmanto D, Garna H. Buku Ajar Nefrologi Anak. Edisi Keti. Jakarta: Ikatan Dokter Anak Indonesia; 2017. 422-430 p.

3. Yuly. Purpura Henoch-Schönlein. 2012;39(6):413-5.

4. Yang $\mathrm{YH}, \mathrm{Yu} \mathrm{HH}$, Chiang BL. The diagnosis and classification of Henoch-Schönlein purpura: An updated review. Autoimmun Rev. 2014;13(4-5):355-8.

5. Roberts PF, Walle TA, Brinker TM, Riffe IZ, Sayre JW, Bratton RL. Henoch-Shonlein Purpura: A Review Article. South Med J. 2007;100(8):821-4.

6. Suzy A, Pertiwi P, Kedokteran D, Anak G, Gigi FK. Henoch-Schönlein Purpura in Children: its Relation to Oral and Dental Health. Dent J (Maj Ked Gigi). 2012;45(3):127-32.

7. Abe M, Mori Y, Saijo H, Hoshi K, Ohkubo K, Ono T, et al. The efficacy of dental therapy for an adult case of Henoch-Schönlein purpura. Oral Sci Int. 2012;9(2):59-62.

8. Adyanthaya A, Sreelaksshmi N, Ismail S, Raheema. Barrier to dental care for children with special needs: General dentist's perception in Kerala, India. J Indian Soc Pedod Prev Dent. 2017;35(1):216-22.

9. Hetland LE, Susrud KS, Lindahl KH, Bygum A. Henoch-schönlein purpura: A literature review. Acta Derm Venereol. 2017;97(10):1160-6.

10. Ns K, Riyaz N. Henoch-Scholein Purpura ( HSP ): A Clinico-etiological Study. NJDVL. 2014;12(1):28-33.

11. Ghrahani R, Ledika A, Sapartini G, Setiabudiawan B. Age of onset as a risk factor of renal involvement in Henoch-Schönlein purpura. Asia Pacific Assoc Allergy, Asthma Clin Imunol. 2014;4:42-7.

12. Echavarria-Garcia AC, Pozos-Guillen A, Tejeda-Nava F, Flores Arriaga JC, GarrochoRangel A. Oral management of children with Henoch-Schonlein Purpura and associated Glomerulonephritis: a scoping review. Eur J Paediatr Dent. 2018;19(2):134-8.

13. Tendean S, Siregar SP. Laporan Kasus Purpura Henoch-Schönlein. Sari Pediatr. 2005;7(1):45-9.

14. Lim CED, Cheng LNC, Wong FWS. Could it be Henoch-Schonlein purpura? Aust Fam Physician. 2009;38(5):321-4.

15. Sohagia AB, Gunturu S, Tong TR, Hertan HI. Henoch-Schonlein purpura- a case report and review of the literature. Gastroenterol Res Pract. 2010;1-7.

16. Bluman J, Goldman RD. Henoch-Schonlein purpura in children: Limited benefit of corticosteroids. Can Fam Physician. 2014;60(11):1007-10.

17. Fincati M, Leung AK, Leung AA. Henoch Schonlein Purpura. Int J Clin Med Imaging. 2015;2(4):1000306.

18. Shahzad N, Ahmed S, Rashid I, Jan M, Quyoom S. Clinical Profile and Pattern of Henoch-Schonlein Purpura in Children in Kashmir. IOSR J Dent Med Sci Ver II. 2015;14(5):2279-861.

19. Brailo V, Vidović Juras D, Stanimirović A, Vučićević Boras V, Gabrić D, Vrdoljak DV. Dental infection and dermatological diseases: analysis of ninety-two patients and review of the literature. Acta Clin Croat. 2015;54(1):7782.

20. Herrström P, Högstedt B, Aronson S, Holmén A, Råstam L. Acute glomerulonephritis, Henoch-Schonlein purpura and dental amalgam in Swedisch children: A case-control study. Sci Total Environ. 1996;191(3):27782.

21. Natadiningrat M, Maulinda S, Dharmadji HP, Sutedja E, Suwarsa O. Urtikaria Vaskulitis Normokomplement Pada Anak dengan Henoch-Schonlein Purpura. In: Pertemuan Ilmiah Tahunan XII Perhimpunan Dokter Gigi Spesialis Kulit Kelamin Indonesia "Skin Tumor, Cosmetic and Aesthetical 
Approaches.” 2012. p. 358.

22. Tinsley E. Managing childhood ailments: Henoch-Schonlein purpura. J Heal Visit. 2017;5(5):222-4.

23. Tahmassebi JF, Paterson SA. Development of acute Henoch-Schönlein purpura subsequent to endodontic treatment. Int J Paediatr Dent. 2007;17(3):217-22.

24. Enzenauer RJ, Sutley SH, Enzenauer RW. Recurrent Henoch-Schonlein purpura presenting as gingival petechiae and mandibular pain. J Oral Maxillofac Surg. 1990;48(6):634-7.

25. Inoue $\mathrm{CN}$, Nagasaka $\mathrm{T}$, Matsutani $\mathrm{S}$, Ishidoya M, Homma R, Chiba Y. Efficacy of early dental and ENT therapy in preventing nephropathy in pediatric Henoch-Schönlein purpura. Clin Rheumatol. 2008;27(12):148996.
26. Igawa K, Satoh T, Yokozeki H. Possible association of Henoch-Schonlein purpura in adults with odontogenic focal infection. Int $\mathbf{J}$ Dermatol. 2011;50(3):277-9.

27. Setiabudiawan B, Ghrahani R, Sapartini G, Kadir MR. Infeksi Gigi Sebagai Faktor Pencetus Terbanyak Henoch-Schonlein Purpura dengan Keterlibatan Ginjal. Sari Pediatr. 2013;14(6):369-73.

28. Inoue $\mathrm{CN}$, Matsutani $\mathrm{S}$, Ishidoya M, Homma R, Chiba Y, Nagasaka T. Periodontal and ENT therapy in the treatment of pediatric henochschönlein purpura and IgA nephropathy. Adv Otorhinolaryngol. 2011;72:53-6.

29. Nakaseko H, Uemura O, Nagai T, Yamakawa S, Hibi Y, Yamasaki Y. high prevalence of Sinusitis in Children with Henoch-Schonlein Purpura. Int J Pediatr. 2011;1-3. 